\title{
Acute Coronary Thrombolysis with Recombinant Human Tissue-Type Plasminogen Activator: Initial Patency and Influence of Maintained Infusion on Reocclusion Rate
}

\author{
MARC VERSTRAETE, MD, PhD, ALFRED E.R. ARNOLD, MD, \\ RONALD W. BROWER, PhD, DÉSIRÉ COLLEN, MD, PhD, DAVID P. de BONO, MD, \\ CHFIS DE ZWAAN, MD, RAINER ERBEL, MD, W. STUART HILLIS, MD, \\ R. JOHN LENNANE, MD, JACOBUS LUBSEN, MD, DETLEF MATHEY, MD, \\ DOUGLAS S. REID, MD, WOLFGANG RUTSCH, MD, MICHAEL SCHARTL, MD, \\ JOACHIM SCHOFER, MD, PATRICK W. SERRUYS, MD, MAARTEN L. SIMOONS, MD, \\ RAINER UEBIS, MD, ALEC VAHANIAN, MD, FREEK W.A. VERHEUGT, MD, \\ and RAINER von ESSEN, MD
}

An intravenous infusion of $\mathbf{4 0} \mathrm{mg}$ of recombinant tissue-type plasminogen activator (rt-PA) was given intravenously over 90 minutes to 123 patients with acute myocardial infarction (AMI) of less than 4 hours' duration. A coronary angiogram was recorded at the end of the infusion in 119 patients. Central assessment of the angiograms revealed a patent infarct-related artery in $\mathbf{7 8}$ patients (patency rate $66 \%, 95 \%$ confidence limits 57 to $74 \%$ ). Patients with a patent infarct-related artery at the first angiogram were randomized in a double-blind manner to receive a subsequent 6-hour infusion of either $\mathbf{3 0}$ $\mathrm{mg}$ of rt-PA or placebo. All patients had received an initial bolus of 5,000 IU of heparin and then 1,000
IU/hour until a second angiogram was recorded 6 to 24 hours after the start of the second perfusion. At central assessment of the second coronary angiogram the reocclusion rate was 2 of 36 patients who received rt-PA at the second infusion and 3 of 37 patients not receiving this drug (or the 2 groups combined $7 \%, 95 \%$ confidence limits 2 to $15 \%$ ). Three of 60 patients $(5 \%, 95 \%$ confidence limits 1 to $14 \%$ ) with patent arteries on both previous angiograms had a later occlusion as judged on the angiogram recorded at hospital discharge. No difference in late reocclusion rates between the 2 treatment groups was observed.

(Am J Cardiol 1987;60:231-237)
A M cute coronary thrombolysis with recombinant human tissue-type plasminogen activator (rt-PA) has been shown to be practicable and effective, ${ }^{1-5}$ but uncertainty persists about the most effective dosage schedule, both in terms of total dosage and distribution in time. ${ }^{6}$ To be clinically relevant, thrombolysis requires not only early recanalization, but also long-term maintenance of patency of the infarct-related artery. Different studies have shown widely varying rates of coronary reocclusion during the first hours or days after thrombolysis as documented by repeat angiography. ${ }^{7-24}$ The present trial was performed to determine

\footnotetext{
Committees and Participation Institutions are listed in the Appendix. Manuscript received December 23, 1986; revised manuscript received and accepted April 10, 1987.

Address for reprints: M. Verstraete, Center for Thrombosis and Vascular Research, Campus Gasthuisberg, University of Leuven, Herestraat 49, B-3000 Leuven, Belgium.
}

the early and late predischarge reocclusion rates after patency of the infarct-related artery had been shown by coronary angiography in patients with acute myocardial infarction (AMI) treated with intravenous rtPA. Because reocclusion was reported to occur within 1 hour after cessation of the rt-PA infusion, ${ }^{6}$ an early repeat catheterization was planned at the end of the second infusion: 6 hours after start of the second infusion, the latest after 24 hours. A second aim was to assess whether a continued infusion with rt-PA over 6 hours could prevent early and late reocclusion and further reduce residual stenosis as measured by quantitative coronary angiography. The results of the quantitative angiography, performed with a computer-as. sisted cardiovascular angiography analysis system (CAAS), are reported separately. ${ }^{25}$

\section{Methods}

Patients and management: Inclusion and exclusion criteria wore the samc as for the first 2 European 
trials ${ }^{2,3}$ except that a previous myocardial infarction in a different location did not disqualify the patient for the present study and that all patients had to enter the trial within 4 hours of the onset of pain.

All consenting patients were registered by telephone at a central allocation service. After blood sampling for coagulation and other assays, an intravenous bolus of 5,000 IU of heparin was given and was followed by an intravenous infusion over 90 minutes of 40 mg rt-PA (G-11021, Genentech Inc., supplied by Boehringer Ingelheim International $\mathrm{GmbH}$ ]. Cardiac catheterization was performed as previously reported ${ }^{3}$ and the first sclective coronary angiogram was recorded between 75 and 90 minutes after the start of the rtPA infusion. Coronary angiograms were recorded on $35-\mathrm{mm}$ cine film in all patients except in 10 for whom high-resolution videotape was used for the 90-minute angiogram. After angiography, the local cardiologists made a decision as to whether they regarded the infarct-related vessel as patent or occluded. Patients with a patent infarct-related artery were given heparin as a continuous intravenous infusion of 1,000 IU/hour for at least 24 hours or until the second angiogram was recorded and were randomized to receive in a doubleblind manner either an additional infusion of $30 \mathrm{mg} \mathrm{rt}-$ PA or placebo over 6 hours. Numbered treatment packages contained either rt-PA or an indistinguishable placebo. Allocation was balanced at each clinic.

Serial electrocardiograms and blood samples for cardiac enzyme analysis were taken to confirm the diagnosis of myocardial infarction. Blood samples for central assessment of coagulation factors and rt-PA activity were collected. Coronary angiography was repeated between 6 to 24 hours after start of the second infusion and at the time of hospital discharge.

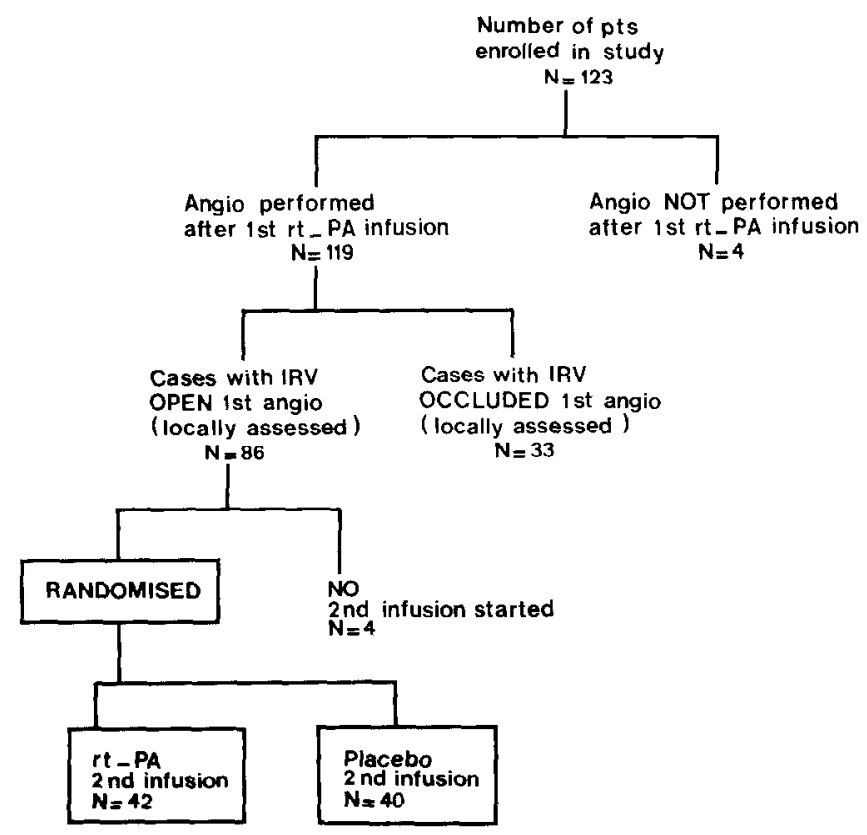

FIGURE 1. Flow diagram of patients in whom rt-PA infusion was given. Subsequent randomization based on local assessment of the patency of the infarct-related artery at first angiogram. IRV = infarct-related vessel.
Assessment of coronary arteriograms: For the angiograms at 6 to 24 hours and before discharge the $x$ ray system was repositioned in projections corresponding as closely as possible to those recorded during the initial angiogram. Angiograms were recorded in multiple views, including hemiaxial views for the left coronary artery. The infarct-related segment was identified for all films on the basis of electrocardiographic and angiographic evidence during a central assessment by teams of 3 assessors (D de $B$ and PS], 2 of whom were always present to maintain consistency.

Qualitative asscssment of patency was performed using a predetermined code: $0=$ normal vessel with complete filling of distal vessels within 3 cardiac cycles $; 1=$ less than $50 \%$ diameter stenosis with complete filling of distal vessels within 3 cycles; 2 = diameter stenosis between $\mathbf{5 0} \%$ and $90 \%$ with complete filling of distal vessels, not through collaterals, within 3 cardiac cycles; $3=$ severe stenosis greater than $90 \%$, but distal vessels fill completely, not through collaterals, within 3 cardiac cycles; $4=$ subtotal occlusion, no distal filling within 3 cardiac cycles; $5=$ total occlusion with or without collateral distal filling. Patency of an infarct-related artery was assessed at the first technically adequate contrast injection and classified as patent in case of grade 0,1,2 or 3 and as occluded in case of grade 4 and 5 .

Blood coagulation and fibrinolytic assays: Blood samples for analysis in the central coagulation laboratory were collected in all patients admitted to the trial before and 60 and 90 minutes after the start of rt-PA infusion. In randomized patients, further blood samples were obtained 2, 4, 6 and 24 hours after the start of the second infusion (rt-PA or placebo). Tubes for blood collection were provided containing $0.5 \mathrm{ml}$ sodium citrate (final concentration $0.01 \mathrm{M} /$ liter). Processing and storage of blood samples and methods to assess coagulation and fibrinolytic components were as described previously. 3,4 The normal values for fibrinogen in plasma is 2 to $4 \mathrm{~g} /$ liter and for fibrinogen degradation products in serum less than $8 \mathrm{mg} /$ liter.

Trial size, data acquisition and statistical analysis: Data collection and analysis were performed by an autonomous data center, independent of the investigators and the sponsor Boehringer Ingelheim International. Continuous data are presented as medians and ranges; $95 \%$ confidence interval of the differences between proportions are given. ${ }^{26}$

\section{Results}

Eleven European centers entered 123 patients in the study over a 6-month period. Mean age was 56 years and median duration from onset of symptoms to initiation of rt-PA infusion was 2.5 hours (range 0.9 to 4.2). Enzyme data at admission were normal. The full dose of rt-PA was administered in all patients except in 1 because the catheterization laboratory was being used for an emergency. Technical or vascular problems prevented coronary angiography in 3 patients. Thus, angiography at 90 minutes after the start of the rt-PA infusion was completed in 119 patients (Fig. 1). 
Patency rate at 90 minutes: Central assessment of the 119 coronary angiograms revealed a patent infarct. related artery in 78 patients (patency rate $66 \%, 95 \%$ confidence intervals 57 to $74 \%$ ). Figure 2 shows the disagreement between locally and centrally assessed patency of the first angiogram. The local cardiologists considered the infarct-related artery to be patent in 8 patients who were randomized to receive a second infusion of rt-PA (5 patients) or placebo ( 3 patients). According to the central angiography evaluation group, the criteria for patency in these 8 patients were not fulfilled either because of sluggish flow in a distal vessel (grade 4 in 3 patients allotted to rt-P $\Lambda$ for second infusion), because the vessel only became patent during later contrast injections [3 patients receiving placebo for second infusion), or because of complete occlusion (1 patient allotted to rt-PA for second infusion].

Of the 86 patients locally judged to have a patent infarct-related artery at initial catheterization, 82 received further heparin and were randomized to either an additional rt-PA infusion $(\mathrm{n}=42$ ) or placebo $(\mathrm{n}=$ 40]. Four patients were not randomized: 2 because of emergency coronary bypass surgery, 1 because of immediate percutaneous transluminal coronary angioplasty (PTCA) and 1 because of hemodynamic deterioration (Fig. 1). Analysis of baseline characteristics shows that randomization was successful in segregating similar groups for the second infusion given in a blinded manner (Table I). Among patients receiving rt-PA the infusion was stopped in 3 because of a large hematoma in the groin, in 1 patient because of emergency PTCA for clinical signs of reocclusion 5 hours after start of the second infusion, and in 1 patient for an unreported reason. In the placebo group 2 patients did not receive the full dose, 1 patient because of hemodynamic deterioration and 1 because of reappearance of chest pain subsequently treated with acylated streptokinase-plasminngen complex intravenonsly.

Reocclusion rate at 6 to 24 hours after start of the second infusion: Between 6 to 24 hours after the start of the second infusion, angiography was performed in 79 of 82 patients allocated to a second infusion of either rt-P $\Lambda$ or placebo. In 3 patients coronary angiography was not performed because of coronary artery bypass grafting, hypotension and impossibility to pass the aorta bifurcation. The median interval between the start of second infusion to 6- to 24-hour angiography was 13 hours, 30 minutes ( $90 \%$ range 6 hours 28 minutes to 24 hours 12 minutes) for the rt-PA group and 15 hours, 6 minutes ( $90 \%$ range 6 hours 9 minutes to 24 hours) for the placebo group.

At the end of the initial rt-PA infusion the number of patients with a patent infarct-related vessel [assessment of angiographic review panel] who showed at the 6- to 24-hour angiogram an occluded infarct-rolatod artery was identical in both treatment arms (Fig. 2): 2 of 36 patients $(6 \%, 95 \%$ confidence interval 1 to $19 \%$ ) randomized to rt-PA at second infusion and 2 of 23 in the placebo group showed an occluded infarct-related artery $[5 \%, 95 \%$ confidence interval 10 to $19 \%)$. One of the 2 patients who had a patent-infarct related artery at the first angiogram and did not receive a second infu-
TABLE I Baseline Characteristics (Median and Range)-Cases in Which the First Angiogram was Performed and Found to be Open as Locally Assessed and Second Infusion Started

\begin{tabular}{lccc}
\hline & $\begin{array}{c}\text { rt-PA at } \\
\text { 2nd Infusion } \\
(n=42)\end{array}$ & $\begin{array}{c}\text { Placebo at } \\
\text { 2nd Infusion } \\
(\mathrm{n}=40)\end{array}$ & $\begin{array}{c}\text { All } \\
\text { Others } \\
(\mathrm{n}=41)\end{array}$ \\
\hline Male & 35 & 33 & 32 \\
Age (yr) & 56 & 55 & 56 \\
Time from onset AMl & $(33-68)$ & $(31-70)$ & $(34-69)$ \\
$\quad$ to start of 1st & 2.3 & 2.7 & 2.4 \\
$\quad$ infusion (hr) & $(0.9-4.2)$ & $(1.2-4.0)$ & $(1.3-4.5)$ \\
Previous AMl & 3 & 1 & 2 \\
Pulmonary rales & 11 & 4 & 8 \\
Medication within 6 hrs & & & \\
$\quad$ before start of 1st & & & \\
$\quad$ rt-PA infusion & & 11 & 6 \\
Nitrates (sublingual) & 9 & 10 & 14 \\
$\quad$ Nitrates (intravenous) & 11 & 0 & 2 \\
Beta blockers & 1 & 11 & 5 \\
Calcium antagonists & 9 & & \\
\hline
\end{tabular}

$\mathrm{AMI}=$ acute myocardial infarction.

sion underwent repeat catheterization at 6 to 24 hours and had an occluded coronary artery. This resulted in an overall 6- to 24 -hour reocclusion rate of $7 \%$ ( 5 of 73 patients, $95 \%$ confidence interval 2 to $15 \%$ ).

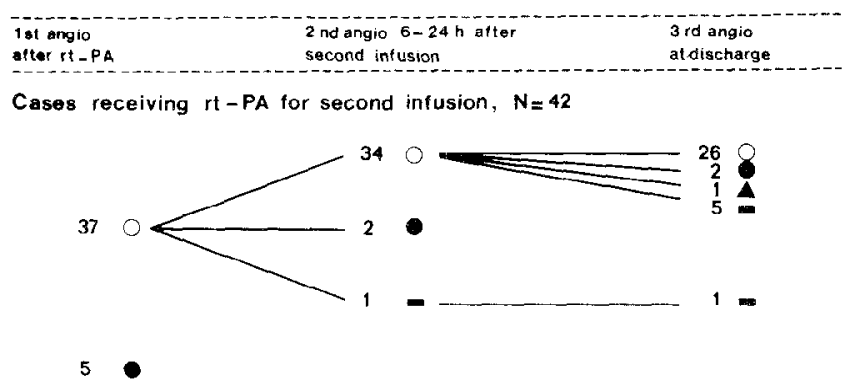

Cases receiving placebo for second infusion, $N=40$

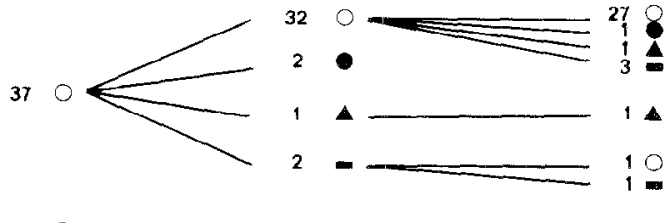

3

Cases ieceiving no second infusion, $N=37$

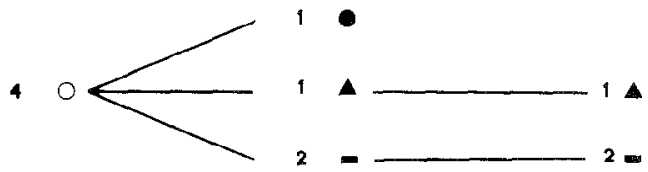

33

FIGURE 2. Status of infarct-related coronary artery at the first, second and third coronary angiogram as assessed by the angio. graphic evaluation group. Status of the infarct-related vessel: circles, open, dots, closed; triangles, patent after intervention; and dash, missing film. Results of the follow-up angiograms performed in patients with an occluded infarct-related vessel are not reported in this figure. 
TABLE II Patients with an Event During Entire Hospital Stay

\begin{tabular}{|c|c|c|c|}
\hline & $\begin{array}{c}\text { rt-PA at } \\
\text { 2nd Infusion } \\
(\mathrm{n}=42)\end{array}$ & $\begin{array}{l}\text { Placebo at } \\
\text { 2nd Infusion } \\
(n=40)\end{array}$ & $\begin{array}{c}\text { All } \\
\text { Others } \\
(n=41)\end{array}$ \\
\hline Ventricular fibrillation & 8 & 2 & 3 \\
\hline $\begin{array}{l}\text { Ventricular tachycardia } \\
\text { (exceeding } 100 \text { beats } / \mathrm{min} \text { ) }\end{array}$ & 13 & 10 & 5 \\
\hline $\begin{array}{l}\text { Chest pain or exacerbation } \\
\text { of chest pain at rest }\end{array}$ & 7 & 6 & 13 \\
\hline Definite reinfarction & 1 & 1 & 2 \\
\hline $\begin{array}{l}\text { Fall in systolic BP } \\
\quad<90 \mathrm{~mm} \mathrm{Hg}\end{array}$ & 5 & 9 & 8 \\
\hline Pulmonary edema & 3 & 2 & 2 \\
\hline Mortallty & 1 & 1 & 4 \\
\hline \multicolumn{4}{|l|}{ Bleeding* } \\
\hline $\begin{array}{l}\text { Hematoma }(>5 \mathrm{~cm} \text { diameter) and/or } \\
\text { prolonged bleeding at puncture sites }\end{array}$ & 12 & 9 & 7 \\
\hline Retroperitoneal bleeding & 1 & - & - \\
\hline Hematuria & 3 & - & 1 \\
\hline Gum bleeding & - & 1 & 1 \\
\hline Blood or plasma transfusion given & 1 & 3 & 3 \\
\hline \multicolumn{4}{|l|}{$\begin{array}{l}\text { Additional interventions } \\
\text { at 1st angio: }\end{array}$} \\
\hline Intracoronary SK & $i_{-}$ & - & 17 \\
\hline Intracoronary SK+PTCA & - & - & 9 \\
\hline $\begin{array}{l}\text { Intracoronary SK+mechanical } \\
\text { perforation }\end{array}$ & - & - & 1 \\
\hline Mechanical perforation + PTCA & - & - & 2 \\
\hline PTCA alone & - & - & 2 \\
\hline PTCA after first catheterization & 7 & 4 & 5 \\
\hline Coronary artery bypass grafting & 3 & 1 & 5 \\
\hline
\end{tabular}

*One patient had hematuria and prolonged bleeding at puncture site, and 1 patient had gum bleeding and hematuria. these patients were classified twice.

$\mathrm{BP}=$ blood pressure; PTCA = percutaneous transluminal coronary angioplasty; SK = streptokinase.

At the predischarge angiography, 1 of the 5 patients with reocclusion at 6 to 24 hours had a patent infarctrelated vessel, 1 patient had a patent vessel after angioplasty, which was performed immediately after second catheterization, 1 patient still had an occluded infarct-related artery and 2 patients did not undergo a catheterization before discharge.

Reocclusion rate at one to four weeks: At the time of hospital discharge, coronary angiography was performed in 69 of the 82 patients who received a second infusion. It was not performed in 13 patients, due to patient refusal $(n=6)$, coronary artery bypass grafting $(\mathrm{n}=6)$ and death $(\mathrm{n}=1)$. In 2 of 29 patients $(7 \%, 95 \%$ confidence interval 1 to $23 \%$ ) in the group receiving rt$\mathrm{PA}$ as a second infusion and in 1 of $30(3 \%, 95 \%$ confidence interval 0 to $17 \%$ ) in the group receiving placebo, late reocclusion occurred (Fig. 2). In the group that did not receive a second infusion, repeat catheterization before discharge was performed in 1 patient; the infarct-related vessel was patent (Fig. 2). Thus, in all groups combined, a late occlusion was found in 3 of 60 patients $(5 \%, 95 \%$ confidence inlerval 1 to $14 \%)$. The median interval from start of the first infusion to the predischarge catheterization was 10 days $(90 \%$ range 7 to 26$)$ for the rt-PA group and 14 days (90\% range 7 to 26) for the rt-PA group for the placebo group. This resulted in a 1- to 4 -week occlusion rate of $7+5=$ $12 \%$. Only 4 of the 8 patients with reocclusion ( 5 early, 3 late) had clinical symptoms of reocclusion.

Outcome of further recanalization attempts in patients with occluded vessel at 90 minutes: The local angiographic assessment was confirmed in the 33 patients with an occluded infarct-related vessel by the central reading. Twenty-eight patients had a completely occluded infarct related artery (grade 5 ) and 5 patients had subtotal occlusion (grade 4). Intracoronary streptokinase was given to 27 patients; 4 patients with grade 4 and 23 with complete occlusion. Although the protocol required intracoronary streptokinase, 1 patient with complete occlusion was treated with intravenous acetylated streptokinase-plasminogen complex (15 mg in 15 minutes). Thus, 5 patients were not treated with streptokinase even though they did not have a patent infarct-related vessel (1 patient refusal, 1 patient with arrhythmias, 1 protocol violation: immediate mechanical perforation, 1 hemodynamic instability, 1 subtotal occlusion). The median dose of intracoronary streptokinase was 120,000 IU (range 4,000 to 262,500 ) and median time of administration 30 minutes (range 15 to 90 ).

Immediate angioplasty was performed in 2 of the patients with an initially subtotal occlusion (in 1 case with streptokinase) and in 10 of 28 patients with an initially occluded vessel (in 2 cases without streptokinase). In 1 patient with a completely occluded infarctrelated vessel, streptokinasc was followed by mechanical perforation.

Local assessment revealed a patent infarct-related vessel in 4 of the 14 patients with a complete occlusion and in 2 of the 3 with subtotal occlusion who were treated with intracoronary streptokinase without mechanical perforation or PTCA. Angioplasty in 12 pa- 
tients and mechanical perforation without PTCA in 1 patient were successful in all but 2 occasions $(85 \%$ ).

Complications: The initial infusion of $40 \mathrm{mg}$ of rtPA administered over 90 minutes was well tolerated and hemodynamic or other complications were rare in 122 patients who received the full dose. The incidence of bradycardia that formed an indication for temporary pacing, ventricular tachycardia and ventricular fibrillation combined was 17 of 123 patients (14\%). These arrhythmias occurred equally frequent in patients who had a patent infarct-related artery at 90 minutes as in those with an occluded vessel. Pyrexia or allergic reactions were not reported, although 1 case of shivering was observed. The events and complications during the entire hospitalization phase are listed in Table II. There werc no differences between those randomized to a second infusion of rt-PA and those allotted to placebo.

During the first rt-PA infusion hemorrhagic complications were limited to 2 patients, 1 with a hematoma at a puncture site and 1 with hematuria. After the first catheterization, bleeding around the sheath was observed in 3 patients; at that time 1 patient received additional streptokinase because of persistent coronary occlusion. During the second infusion, 1 patient had hematuria and 4 others randomized to rt-PA had a large hematoma at the catheter site, while the latter was noted in only 1 patient randomized to placebo infusion. Heparin was stopped in 3 of these patients; 1 received protamin. 'I'he second infusion of rt-PA was stopped in 1 patient.

Table II lists patients with bleeding during the hospital stay. All bleeding events not yet described were observed between the second catheterization and hospital discharge. One patient required surgical arterial repair because of prolonged bleeding that occurred 24 hours after the second rt-PA infusion. A retroperitoneal bleeding developed 1 day after the end of the second rt-PA infusion but did not require special measures. Two patients had hematuria 2 days after rt-PA allocation. No cerebral or gastrointestinal bleeding was seen. 'l'he number of patients with 1 or more bleeding sites was slightly higher in the rt-PA group $( \pm 16)$ than in the placebo group $( \pm 10)$. Blood transfusions were given to 1 patient in the rt-PA group and to 3 patients in the placebo group, all because of large hematoma.

There were 6 in-hospital deaths. In the group of patients without a second infusion, 4 died: 1 from reinfarction, 1 from cardiogenic shock, 1 from asystole and 1 perioperatively. Among the patients who had received rt-PA as a second infusion, 1 patient died during predischarge catheterization due to asystole followed by electromechanical dissociation. Among the patients receiving placebo as a second infusion, 1 patient died due to a myocardial rupture. The first catheterization was complicated in 1 patient with aortic root dissection, which was treated conservatively. The second catheterization in 1 patient was complicated by right ventricle perforation by a pacemaker catheter; cardiac surgcry was required.

Central assessments of electrocardiograms: All electrocardiograms were reevaluated by 2 indepen-
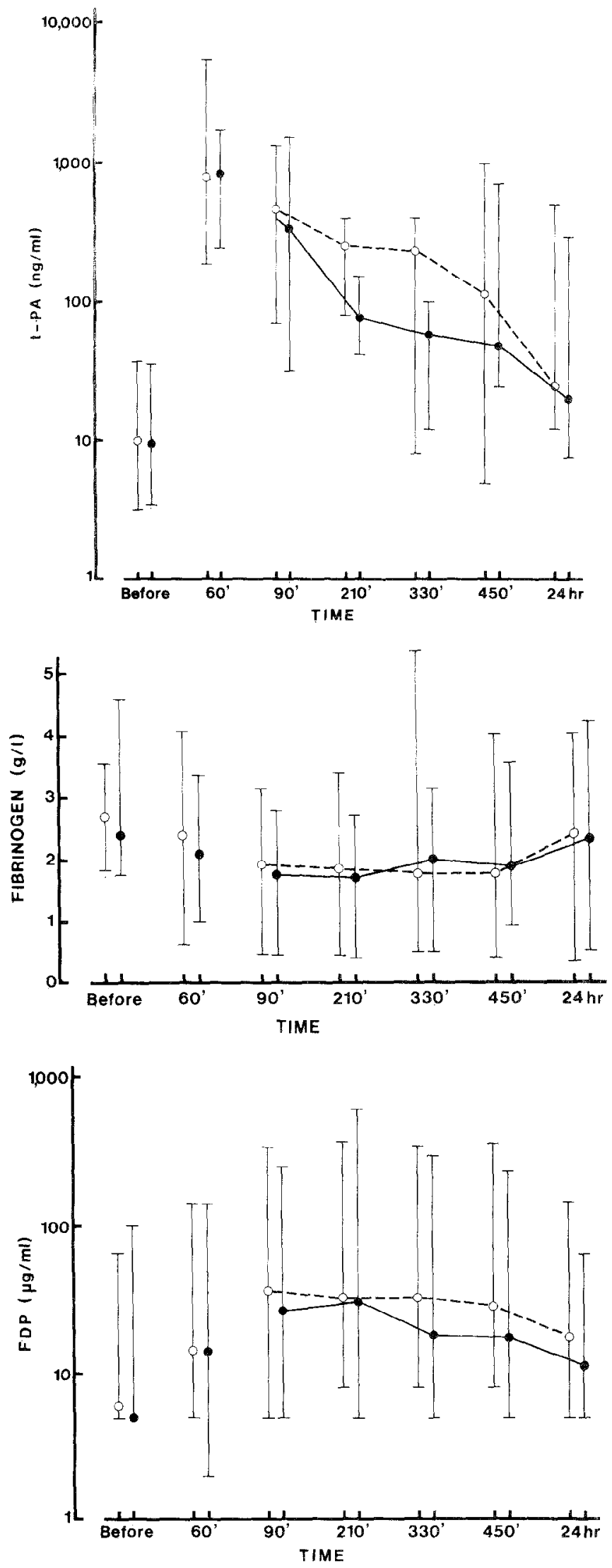

FIGURE 3. Levels of rt-PA antigen, fibrinogen and fibrinogen degradation products (FDP) in plasma during the initial infusion of $r t-P A$ ( $40 \mathrm{mg}$ in first 90 minutes) in all randomized patients and during subsequent rt-PA infusion ( $30 \mathrm{mg}$ over 6 hours) (circles) or placebo infusion ( 6 hours) (dots). 
dent readers. The admission electrocardiograms of 3 patients could not be retrieved for central analysis. Of 120 patients, 106 showed more than $0.2 \mathrm{mV}$ of STsegment elevation in 2 limb leads or more than $0.3 \mathrm{mV}$ in 2 precordial leads as required by the protocol (anterolateral in 64 patients, inferoposterior in 42). In 14 patients ST-segment elevation was present but of lesser magnitude (anterolateral in 2 patients, inferoposterior in 11 and undefined in localization in 1 patient]. The final diagnosis of myocardial infarction was confirmed by electrocardiographic criteria and enzyme elevation exceeding twice the upper limit of normal in 116 patients and by electrocardiogram alone in 7 (in 2 patients no diagnostic enzyme increase, in 5 patients insufficient enzyme data).

Blood coagulation and rt-PA assay: The median radioimmunoreactive rt-PA levels for patients in = 100 ) analyzed at 60 minutes after the start of the 1st rtPA infusion was $800 \mathrm{ng} / \mathrm{ml}$ (range 189 to 5,440 ) (Fig. 3). The median fibrinogen concentration of all patients analyzed decreased from $2.6 \mathrm{~g} /$ liter (range 1.7 to 4.6 ) to $1.8 \mathrm{~g} /$ liter (range 0.1 to 3.2 ) (23\%) at the end of the first infusion (90 minutes), without further reduclion during the maintenance infusion of $30 \mathrm{mg}$ of rt-PA over the next 6 hours. The median level of fibrinogen was $72 \%$ of the starting value at the end of the first infusion and $65 \%$ as lowest value during subsequent maintenance infusion.

\section{Discussion}

Reocclusion is a major problem after coronary recanalization in the setting of acute myocardial infarction. Two weeks after intracoronary streptokinase, the reocclusion rate varies between less than $10 \%$ to $29 \% .8,9,11,14-20$ Pooling the data of all these studies, 61 of 311 patients had an angiographically documented reocclusion $(17 \%, 95 \%$ confidence limits 13 to $21 \%$ ). The first studies ${ }^{5,6}$ that evaluated the early reocclusion rafes after successful recanalization with intravenous rt-PA reported rates of $33 \%$ (95\% confidence limits 15 to $57 \%)^{5}$ and $46 \%$ (95\% confidence limits 23 to $\left.83 \%\right)^{6}$ However, the wide range of the $95 \%$ confidence limits made definite conclusions impossible. The present study suggests a reocclusion rate comparable to the reocclusion rate after intracoronary streptokinase.

It could be argued that due to our strict criteria for patency, we excluded from analysis the patients with subtotal occluded vessels (grade 4 ) and the patients in whom the infarct-related vessel opened during later contrast injections who could be prone for reocclusion on the short term. Repeat analysis including these patients $[\mathrm{n}=4$ in the group receiving rt-PA as second infusion and $n=3$ in the group randomized to placebo] added 1 patient with a reocclusion at 6 to 24 hours, resulting in a 6- to 24-hour reocclusion rate of 6 of 80 patients $(8 \%, 95 \%$ confidence limits 3 to $16 \%)$. At 1 to 4 weeks, no more patients with reocclusion were found ( 3 of 65 patients with patent vessels at both previous films). Hence, we conclude that our definition of patency does not have a major influence on the results. A second possible explanation for the low reocclusion rate in the present study is that patients with already patent vessels before treatment $(21 \%$ according to one of our previous studies using very similar selection criteriaj $^{2}$ are less susceptible to reocclusion, perhaps because the cause of the initial occlusion was transient coronary spasm. ${ }^{27}$

Finally, the reocclusion rate reported here could be underestimated because of the missing angiograms at 6 to 24 hours in 5 patients and at hospital discharge in 12 (Fig. 2). To determine the magnitude of the bias that has been introduced thereby, we recalculated the occlusion rates assuming that patients who did not undergo recatheterization because of coronary bypass operation or death were patients with reocclusion. Applying this definition to the 6- to 24-hour angiogram, 1 patient was added in the group receiving rt-PA as second infusion and 2 patients in the group without a second infusion, resulting in a reocclusion rate at 6 to 24 hours of $11 \%$ ( 8 of 76 patients). Regarding the predischarge angiogram, 3 patients were added in the group receiving rt-PA as second infusion and 2 patients in the group receiving placebo as second infusion (1 to 4 weeks reocclusion rate $12 \%, 8$ of 65 patients). Thus, the overall reocclusion rate, applying the assumption mentioned above, was $23 \%$. This indicates that patients lost to follow-up cannot completely account for the disparity between the reocclusion rate of the present study and that of previous studies. ${ }^{5,6}$

We failed to show a further reduction of the reocclusion rate by an additional 6 hours infusion of rt-PA. Nevertheless, quantitative analysis of the angiograms showed a greater reduction in residual stcnosis in the group receiving rt-PA as a second infusion. ${ }^{25}$ It has been suggested ${ }^{23,28}$ that the presence of residual thrombus after recanalization is a major cause of reocclusion. Furthermore, several studies show that reocclusion mainly occurs in patients with severe residual stenoses. $6,7,12,16$ This is not confirmed by the present study. Agnelli et al ${ }^{29}$ using a venous thrombosis model in the rabbit, showed that the thrombolytic activity of rt-PA persists within the thrombus for several hours after rt-PA was cleared from the circulation. This may explain the low reocclusion rate in our patients.

Notwithstanding the fibrinogen sparing properties of rt-PA, bleeding was the most frequent complication after thrombolysis with rt-PA. Most bleeding complications were related to the 90 -minute catheterization. There was a tendency of more frequent bleeding in the group receiving rL-PA as a second infusion, although no difference in fibrinogen levels was seen during the first 24 hours. Also, most other events mentioned in Table II were more frequently seen in the group receiving rt-PA as second infusion.

Intracoronary streptokinase appeared effective in only $35 \%$ of the patients in whom the initial treatment with rt-PA was not successful. This means that additional interventions are needed. PTCA and mechanical perforation were successful in $85 \%$ of the cases.

This study also shows that clinically silent reocclusion occurs in many patients with recanalization and that silent reocclusion may be transient. The latter finding shows that recanalization alone is not a clinically relevant achievement. Harder endpoints such as left ventricular function and mortality to assess clinical benefits of thrombolysis with rt-PA are needed. 


\section{References}

1. Collen D, Topol EJ, Tiefenbrunn AJ, Gold HK, Weisfeldt ML, Sobel BE, Leinbach RC, Brinker JA, Ludbrook PA, Yasuda T, Bulkley BH, Robison AK, Futter AM, Bell WR, Spadaro J]. Khaw DA, Grossbard DE. Coronary thrombolysis with recombinant human tissue-type plasminogen activator: a prospective, randomized, plucebo-iontrolled trial. Circulation 1984;70:10121017 .

2. Verstraete M, Bleifeld W, Brower RW, Charbonnier B, Collen D, de Bono DP, Dunning AI, Lennane RI, Lubsen I, Mathey DG, Michel PL, Raynaud PH, Schofer I, Vahanian A, Vanhaecke I, Van de Kley GA, Van de Werf F, von Essen R. Double-blind, randomized trial of intravenous tissue-type plasminogen activator versus placebo in acute myocardial infarction. Lancet 1985;2: 965-969.

3. Verstraetc M, Bernard R, Bory M, Brower RW, Collen D, de Bono DP, Erbel R. Huhmann W, Lennane RJ, Lubsen J, Mathey D, Meyer I. Michels HR, Rutsch W, Schartl M, Schmidt W. Uebis R, von Essen R. Randomized trial of intravenous recombinant tissue-type plasminogen activator versus introvenous streptokinase in acute myocardial infarction. Lancet 1985;1:842-847. 4. TIMI Study Group. The Thrombolysis in Myocardial Infarction (TIMI) trial. Phase I findings. $N$ Engl I Med 1985:312:932-936.

5. Williams DO, Borer J, Braunwald E, Chesebro JH, Cohen LS, Dalen J, Dodge HT, Francis CK, Knatterud G, Ludbrook P, Markis JE, Mueller $\mathrm{H}$, Desvigne-Nickens P, Passamani ER, Powers ER, Rao AK, Roberts R, Ross A Ryan TI. Sobel BE. Winniford M, Zaret B, Co-investigators. Intravenous recombinant tissue-type plasminogen activator in patients with acute myocardial infarction: o report from the NHLBI thrombolysis in myocardial infarction rial. Circulation 1986;73:338 316

6. Gold HK, Lein bach RC, Garabedian HD, Yasuda T, Johns JA, Grossbard $\mathrm{EB}$, Palacios I, Collen D. Acute coronary reocclusion after thrombolysis with recombinant human tissue-type plasminogen activator: prevention by a maintenance infusion. Circulation 1986;73:347-352.

7. Cowley MJ, Hastillo A, Vetrovec GW, Hess ML, Effect of intracoronary streptokinase in acute myocardial infarction. Am Heart T 1981;102:11491159.

8. Merx W, Dörr R, Rentrop P, Blanke H, Karsch KR, Mathey DG, Kremer P, Rutsch W, Schmutzler H. Evaluation of the effectiveness of intracoronary streptokinase infusion in acute myocardial infarction: post procedure management and hospital course in 204 patients. Am Heart I 1981;102:11811187.

9. Schwar\% F, Schuler Cr, Katus H, Mehmel HC, Olshausen KV, Hofmann M, Hermann HJ, Kübler $W$. Intracoronary thrombolysis in acute myocardial infarction: correlations among serum enzyme, scintigraphic and hemodynamic findings. Am I Gordiol 1982;50:32-38.

10. Timmis GC, Gangadharan V, Hauser AM, Ramos RG, Wostveer DC, Gordon S. Intracoronary streptokinase in clinical practice. Am Heart I 19,82;104:925-938.

11. Cribier A, Berland I, Champoud O. Moore N, Dehar P. Letac B. Intracoronary thrombolysis in evolving myocardial infarction. Sequential angiographic analysis of left ventricular performance. Br Heart J 1983;50:401-410.

12. Neuhaus KL, Tebbe B, Saner G, Verewzer H, Kustering H. High dose intravenous streptokinase in acute myocardial infarction. Clin Cardiol 1983; 6:426-434.

13. Schröder R, Biamino G, von Leitner ER, Linder T, Brüggemann T, Heitz J, Vöhringer HF, Wegscheider K. Intravenous short-term infusion of streptokjnase in acute myocardial infarction. Circulation 1983;67:536-548.

14. Erbel R, Pop I', Henrichs KJ, Von Olshausen K, Schuster CJ, Rupprecht IIJ. Steuernagel C, Meyer J. Percutaneous transluminal coronary angioplasty after thrombolytic therapy: a prospective controlled randomized trial. TACO 1986;8:485-495.

15. Serruys PW, Wijns W. Van den Brand M, Ribeiro V. Fioretti P. Simoons $\mathrm{ML}$, Kooijman C], Reiber |H, Hugenholtz PI. Is transluminal coronary angioplasty mandatory after successful thrombolysis? Quantitative coronary angiographic study. Br Heart I 1983;50:257-65.

16. Rogers WJ, Mante JA, Hood WP, Baxley WA, Whitlow PL, Reevers RG, Soto B. Prospective randomized trial of intravenous and intracoronary streptokinase in acute myocardial infarction. Girculation 1983;68:1051-1061.

17. Rontrop KP, Feit F, Blanke H, Stccy P, Schneider R, Rey M, Horowitz S Goldman M, Karsch K, Meilman $H$, Cohen M, Siegel S, Sanger J, Slater J, Gorlin R, Fox A, Fagerstrom R, Calhoun WF. Fiffects of introcoronory streptokinase and intracoronary nitroglycerine infusion on coronary angiographic patterns and mortality in patients with acute myocardial infarction. $N$ Engl Med 1984;311:1457-1463.

18. Charuzi $Y$, Beeder C, Marshall LA, Sasaki H, Pack NB, Geft I, Ganz W. Improvement in regional and global left ventricular function after intracoronary thrombolysis: assessment with two-dimensional echocardiography. Am I Cardiol 1984;53:662-665.

19. Harrison DG, Ferguson DW, Collins SM, Skorton DJ̄, Ericksen EE, Kioschos JM, Marcus ML, White GW. Rethrombasis after reperfusion with streptokinase: importance of geometry of residual lesions. Circulation 1984;69:991999.

20. Ferguson DW, White CW, Schwartz JL, Braydon GP, Kolly KJ, Kioschos JM, Kirchner PT, Marcus ML. Influence of baseline ejection fraction and success of thrombolysis on mortality and ventricular function after acute myocardial infarction. Am I Cardiol 1984;54:705-711.

21. Spann JF, Sherry S, CarabelIo BA, Denenberg BS, Mann RI, McCann
WD, Gault JH, Gentzler RD, Belber AD, Maurer AH, Cooper EM, Goronary thrombolysis by intravenous sheptohinust in acute myocardial infarction: acute and follow-up studies. Am / Cardiol 1984;53:655-661.

22. Schröder R, Vöhringer II, Lindler T, Biamino G, Bruggeman T, Letter ER Follow-up after coronary arterial reperfusion with intravenous streptokinase in relation to residual myocardial infarct artery narrowings. Am I Cardiol 1985;55:313-317

23. Erbel R, Pop T, Meinertz T, Kasper W, Schreiner G, Henkel B, Henrichs KJ, Pfeiffer C, Rupprecht IJ], Meyer J. Combined medical and mechanical recanalization in acute myocardial infarction. Cathet Cardiovasc Diagn 1985;11:361-377.

24. Simoons ML, Serruys PW, van de Brand M, Bár F, de Zwaan C, Res J, Verheugt FWA, Kraus XH, Remme W], Vermeer F, Lubsen I. Improved survival after early thrombolysis in acute myocardial infarction. A randomized trial conducted by the ICI in the Netherlands. Lancet 1985;2:578-581. 25. Serruys PW, Arnold AER, Brower RW, de Bono D, Bokslag M, Lubsen \}, Reiber JHC, Rutsch W. Uebis R, Vahanian A, Verstraete M. Effect of continued $r t-P \Lambda$ administration on the residual stenosis after initially successful recanalization in acute myocardial infarction: a quantitative coronary angiography study of a randomized trial. Eur Heart I 1987, in press.

26. Thomas DG, Gart JJ. A table of exact confidence limits for differences and ratios of two proportions and their odd ratios. I Am Stat Soc $19 / 7 ; / 2 ; / 3-1 / 6$ 27. Maseri A, L'Abbate A, Baroldi G, Chierchia S, Marzilli M, Ballestra AM. Severi S, Parodi O, Biagini A, Distante A, Pesola A. Goronary vasospasm as a possible cause of myocardial infarotion: a conclusion derived from the study of "preinfarction" angina. $N$ Eingl I Med 1978:299:1271-1277.

28. Gash AK, Spann JP, Sherry S, Belber AD, Garabello BA, McDonaugh MT, Mann RH, McCann WD, Gault IH, Gentzler RD, Kent RL. Factors influencing reocclusion after coronary thrombolysis for acute myocardial infarction. Am I Cardiol 1986;57:175-177.

29. Agnelli G, Buchanan MR, Fernandez F, Van Ryn J, Hirsh J. Sustained thrombolysis with DNA-recombinant tissue-type plasminogen activator in rabbits. Blood 1985;66:399-401

\section{Appendix}

Steering Committee: M. Verstraete, Leuven, chairman; R.J. Lennane, Ingelheim, clinical coordinator; D.P. de Bono, Edinburgh; J. Lubsen, Rotterdam; D. Mathey, Hamburg: R. von Essen, Aachen.

Advisory Board: J. Hampton, Nottingham; H.J. Jesdinsky, Düsseldorf; D.G. Julian, Newcastlc-uponTyne; W. Schaper, Bad Nauheirn; L. Wilhelmsen, Göteborg.

Data Center: J. Lubsen, R. W. Brower, A.E.R. Arnold, M. Bokslag, B. Bos-Wolvers, Rotterdam.

Angiography Evaluation Group: D.P. de Bono, Edinburgh, secretary; W.S. Hillis, Glasgow; D. Reid, Newcastleupon-Tyne; W. Rutsch, Berlin; P.W. Serruys, Rotterdam.

Central Coagulation Laboratory: D. Collen, H.R. Lijnen, Leuven.

Participating Clinical Centers: Innere Medizin I, Rheinisch-Westfälische Technische Hochschulc, Aachen (S. Effert, R. von Essen, R. Uebis, W. Schmidt); Academisch Ziekenhuis van de Vrije Universiteit, Amsterdam (F.W.A. Verheugt, A.J. Funke Kuepper, J. Res); Klinikum Charlottenburg, Freie Universität BerIin (H. Schmutzler, W. Rutsch, M. Schartl]; Royal Infirmary Edinburgh (D.P. de Bono, M. Been); Stobhill General Hospital, Glasgow (F.G. Dunn, W.S. Hillis, K.J. Hogg, R.S. Hornung);

2 Medizinische Universitätsklinik, UK Eppendorf, I lamburg (W. Bleifeld, D. Mathey, J. Schofer); Sint Annadal Ziekenhuis, Maastricht (C. de Zwaan, H.J.J. Wellens); II. Medizinische Klinik und Poliklinik, Johannes Gutenberg-Universität, Mainz (J. Meyer, R. Erbel, K.J. Henrichs, T. Pop); Freeman Hospital, Newcastle-upon-Tyne (D.S. Reid); Hôpital Tenon, Paris (J. Acar, A. Vahanian, P.L. Michel, J.M. Weberl; Thorax Center, Erasmus Universiteit, Rotterdam (P.G. Hugenholtz, P.W. Serruys, M.L. Simoons]. 